\title{
PHYTOCHEMISTRY AND PHARMACOLOGY OF PTEROCARPUS SANTALINUS AND ITS ROLE IN DERMATOLOGY
}

\author{
MOHINI KUCHEKAR ${ }^{1 *}$, VIJAY NAVGHARE ${ }^{2}$, AMRITA KULKARNI ${ }^{1}$, AISHWARYA ZAMBARE ${ }^{1}$, BHARTI CHOUDHARY ${ }^{1}$
}

${ }^{1}$ Progressive Education Society's Modern College of Pharmacy, Nigdi, Pune, Maharashtra, India. ${ }^{2}$ School of Pharmacy, Swami Ramanand Teerth Marathwada University, Nanded, Maharashtra, India. Email: mohini.kuchekar@gmail.com

Received: 30 August 2021, Revised and Accepted: 25 November 2021

\section{ABSTRACT}

The review provides an updated overview of the phytochemical and pharmacological studies on Pterocarpus santalinus. Phytochemical analysis suggests the presence of triterpenoids, steroids, flavonoids and phenolic acids. The phytoconstituents and related pharmacological activities of various parts of $P$. santalinus include antifungal, anticholinesterase, antidiabetic, antibacterial, antipyretic, anti-inflammatory, anticancer and antiulcer. Literature survey highlights the dermatological applications of the phytoconstituents such as pterostilbene, savinin and betulin as potential leads for anti-aging, ultraviolet rays (UV-B) protective and wound healing effects. Undoubtedly, P. santalinus has wide therapeutic value. The dermatologically significant phytoconstituents, namely, pterostilbene, cedrol, savinin, lupeol, betulin, $\beta$-eudesmol and $\alpha$-bisabolol, if isolated and used in dermatological formulations, can show promising skin protective effect. The data were compiled using scientific databases, namely, Google Scholar and PubMed, the data made available specifically from 2010 to 2021.

Keywords: Pterocarpus santalinus, Pharmacology, Dermatology, Fabaceae.

(C) 2022 The Authors. Published by Innovare Academic Sciences Pvt Ltd. This is an open access article under the CC BY license (http://creativecommons.org/ licenses/by/4.0/) DOI: http://dx.doi.org/10.22159/ajpcr.2022v15i1.43011. Journal homepage: https://innovareacademics.in/journals/index.php/ajpcr

\section{Highlights}

- Brief data on the vernacular names, geographical distribution, traditional uses, collection and cultivation covered.

- Updated overview of the phytochemical and pharmacological studies on P. santalinus

- Dermatological applications of the phytoconstituents of P. santalinus.

- Diverse applications of P. santalinus were discussed.

\section{INTRODUCTION}

Pterocarpus santalinus Linn. belongs to the family Fabaceae, popular as "Red Saunders," it is deciduous plant growing up to 10-11 m high. Geographical distribution of $P$. santalinus is cultivated in the southern parts of Eastern Ghats. Commercially important part is timber of $P$. santalinus which has historical and traditional value, used for the production of acoustical instruments, toys and carvings. Convention on International Trade in Endangered Species of Wild Fauna and Flora has listed $P$. santalinus as an endangered plant [1].

Santalin, a natural dye in the timber, is used as a pharmaceutical colorant. Correlation of various phytoconstituents with the pharmacological and dermatological applications urges to compile the data.

\section{VERNACULAR NAMES}

English: Red Saunders, Red sandalwood, Marathi: Raktachandan, Gujarati: Ratanjali, Lalchandana, Kannada: Raktachandana, Telugu: Errachandanamu and Assamese: Sandale [2].

\section{GEOGRAPHICAL DISTRIBUTION}

P. santalinus is distributed in hilly regions with hot and dry climate. It grows well in the tropical regions of India, Sri Lanka, Taiwan, the Philippines and China. In India, it is predominantly found in the southern parts of the Eastern Ghats, Cuddapah and Chittoor districts of Andhra Pradesh and Prakasam and Nellore in Tamil Nadu [3].

\section{CULTIVATION AND COLLECTION}

The seed and vegetative propagation is the traditional way of propagation of $P$. santalinus. In seed germination, it needs well-drained red loam soils which are suitable for the cultivation. It regenerates very well in dry hot climate. It requires rainfall ranging from 800 to $1000 \mathrm{~mm}$ annually for growth. The seeds are given treatment with GA3 (gibberellic acid) and benzyladenine (parts per million) which help in early germination or seeds can be soaked for $72 \mathrm{~h}$ in cold water or in cow dung slurry. The pits (size $45 \times 45 \times 45 \mathrm{~cm}$ are dug at spacing of 4 $\times 4 \mathrm{~m}$ ) are filled with topsoil mixed carefully with $10-15 \mathrm{~kg}$ farm yard manure and $10 \mathrm{~g}$ of lindane dust. It protects the planting stock from attack of soil-borne fungi. March-May months are very much suitable for raising nursery beds from seeds. The best time for planting the crop in the field is end of May-June, that is, onset of rainy season. The irrigation to plants is done immediately after transplantation. Further, alternate days up to 15 days irrigation are done [4].

\section{TRADITIONAL USES}

Ethnobotanical uses of $P$. santalinus include its application in the treatment of boils, eczema and wounds in West Bengal [5]. Powder or decoction of heartwood or bark was used to treat pimples, diabetes and hypercholesteremia in Kerala [6]. P. santalinus (tribes in Chittoor district of Andhra Pradesh) used to treat for ulcers. In Malamalasar tribes of Kerala used wood paste as a blood purifier and antidote to prevent the poison from functioning or reverse its effect. The tribes of Kandhas in Kandhamal, Odisha, administered decoction of Calamus tenuis roots, stem bark of Azadirachta indica and P. santalinus used to treat treating piles [7].

\section{PHYTOCHEMISTRY OF P. SANTALINUS}

Table 1 classifies and enlists the phytoconstituents of $P$. santalinus [8-10]. Fig. 1 depicts the chemical structures of some of the phytoconstituents.

\section{PHARMACOLOGICAL ACTIVITIES OF P. SANTALINUS}

\section{Anticholinesterase (AChE) activity}

The methanol extract of bark of $P$. santalinus possessed in vitro and in vivo AChE activity. In vitro inhibitory assay of AChE by the extract was evaluated by IC50 value and physostigmine as a standard. In vivo activity was assessed in scopolamine induced amnesia in Swiss albino mice. In passive shock avoidance test, increasing concentrations of extract exhibited memory enhancement by increased latency time 
and inhibited brain AChE activity. The terpenoids were found to be responsible for the neuroprotective effects [11].

\section{Antifungal activity}

Ethyl acetate extract of leaves of $P$. santalinus exhibited significant antifungal activity against Trichophyton mentagrophytes, Epidermophyton floccosum, Trichophyton rubrum, Trichophyton simii and Magnaporthe grisea. Complexation of flavonoids in P. santalinus with soluble proteins and the fungal cell wall and subsequent disruption of the cell wall led to the antifungal effect [12]

\section{Antidiabetic activity}

Aqueous, ethanol and hexane bark extracts of $P$. santalinus proved to be antihyperglycemic in normal and alloxan monohydrate-induced diabetic male Wistar albino rats. Ethanol extract showed remarkable hypoglycemic activity. Hypoglycemic effect was attributed due to the phytoconstituents $\beta$-sitosterol, epicatechin and lupeol which activated the remnant beta cells, improved insulin response at cellular level, or had insulin-like effect [13].

Oral treatment of ethyl acetate-methanol fraction of the ethanolic extract of $P$. santalinus decreased elevated blood glucose levels, glycosylated hemoglobin level $\left(\mathrm{HB} 1_{\mathrm{AC}}\right.$ ) by stimulating remnant $\beta$-cells in pancreas as a result, increased hexokinase and glucose-6-phosphate dehydrogenase activity, promoting glycolysis and glucose utilization in diabetic rats. Increase in plasma insulin levels suppressed the activities of hepatic glucogenic enzymes, glucose-6-phosphatase and fructose-1, 6-biphosphatase [14]

\section{Antipyretic activity}

Vasudevan et al. studied the effect of aqueous extract of heartwood of $P$. santalinus on brewer's yeast-induced pyrexia in Wistar rats. Increasing concentrations of the extract proved to be antipyretic by reducing the rectal temperature. The phytochemicals mainly flavonoids, alkaloids and saponins in P. santalinus prevent activation of cyclooxygenase and prostaglandin formation and exhibit antipyretic activity [15].

\section{Antibacterial activity}

Methanol extract of stem bark and leaves possessed dose-dependent antibacterial action against Gram-positive and Gram-negative bacteria. The stem bark extract inhibited the growth of Enterobacter aerogenes, Alcaligenes faecalis, Escherichia coli, Pseudomonas aeruginosa, Proteus vulgaris, Bacillus cereus, Bacillus subtilis and Staphylococcus aureus. The leaf extract inhibited E. coli, A. faecalis, E. aerogenes and P. aeruginosa. The secondary metabolites such as flavonoids and tannins inhibited the bacterial growth by disruption of bacterial cell wall and inactivation of microbial enzymes, transport proteins and adhesins [16].

Gold nanoparticles formulated using $P$. santalinus bark extract showed bacteriostatic effect against pathogenic bacteria $S$. aureus and $P$. aeruginosa [17]

\section{Anti-inflammatory activity}

P. santalinus gel formulation was effective against Complete Freund's Adjuvant-induced rat hind paw inflammation and pain. Reduction in inflammation was assessed by reduction in the paw volume, body weight due to decreased edema and paw withdrawal test proved the analgesic activity. Anti-inflammatory effect may be due to savinin, a lignan, which inhibited inflammatory markers such as tumor necrosis factor- $\alpha$ (TNF- $\alpha)$ and T-cell proliferation. P. santalinus gel was effective in chronic inflammation and could be used in arthritis-like conditions [18].

Lignans, savinin and calocedrin from $P$. santalinus by the virtue of its $\alpha$-arylidene- $\gamma$-lactone structure could significantly inhibit TNF- $\alpha$ in lipopolysaccharide-stimulated RAW264.7 cells and concanavalin elicited T-cell proliferation in BALB/c mice splenocytes [19].

\section{Hepatoprotective activity}

In vitro free radical scavenging activity of the methanol extract of heartwood of $P$. santalinus against oxidative stress induced by DPPH and nitric oxide radicals suggested increased radical scavenging activity dose dependently. In vivo hepatoprotective activity of PSE against alcohol-induced oxidative damage in rat liver was demonstrated by normalized levels of liver damage biomarkers alkaline phosphatase, plasma transaminases, lactate dehydrogenase and gamma glutamyl transferase. Increased level of antioxidant enzymes like glutathione peroxidase (GPx), glutathione S-transferase (GST), glutathione reductase (GR), superoxide dismutase (SOD) and catalase in liver was observed. Phytochemicals such as pterostilbene, lignan and lupeol possess hepatoprotective action [20].

\section{Antioxidant activity}

Ghali et al. studied the antioxidant and radioprotective effects of chloroform extract of $P$. santalinus. Antioxidant potential was significant against ABTS, DPPH and nitric oxide radicals. In vitro radioprotection of murine splenic lymphocytes against gamma radiation by the extract resulted from inhibition radical propagation, DNA strand breakage, lipid peroxidation and thiol depletion. It is a radioprotector which is effective in cancer radiotherapy and radiation-induced malignant tumors [21].

\section{Cytotoxicity against cervical and breast cancer cell lines}

In the study by Donga et al., methanol extracts of stem, leaf and bark of $P$. santalinus proved cytotoxic against cervical and breast cancer cell lines by MTT (3-[4,5-dimethylthiazol-2-yl]-2,5-diphenyltetrazolium bromide) assay. Maximum cytotoxicity or minimum cell viability of the cancer cell lines was exhibited by bark extract [22].

\section{Anti-tumor activity}

Oral administration of ethanolic seed extract of P. santalinus $(300 \mathrm{mg} / \mathrm{kg})$ showed inhibitory effect on 7,12-dimethylbenz(a)-anthracene-induced malignant breast tumor in rats. Anti-tumor activity was assessed by inhibition of tumor growth, reduced malondialdehyde and reduced serum TNF- $\alpha$ in extract treated group, suggesting antioxidant action against breast cancer. Histopathological studies on the tumor tissue in extract-treated group suggest the presence of mature fibroblast cells and hence reduced growth of the. Moreover, hypoglycemic effect was observed in treated group. Hepatotoxicity and renal toxicity due to 7, 12-dimethylbenz(a)-anthracene were found to be reversed by decrease in levels of hepatic serum biomarkers (total serum bilirubin, alanine transaminase, aspartate transaminase and alkaline phosphate) and kidney serum biomarkers (urea, creatinine and uric acid) aiding advantage to be used as an anti-cancer agent [23].

\section{Nephroprotective activity}

In the study by Bulle et al., chronic alcohol consumption caused kidney damage in rats. It was characterized by increased plasma urea and creatinine levels. Hyponatremia, hypokalemia, hypomagnesemia, hypocalcaemia and hypochloremia were evident. Kidney damage markers and decreased level of antioxidant enzymes were observed. $P$. santalinus heartwood methanol extract protected against alcoholinduced glomerular damage and decreased plasma urea and creatinine levels. Reversal of $\mathrm{Na}+\mathrm{K}+$ ATPase activity led to decreased $\mathrm{Na}+\mathrm{K}+$, $\mathrm{Ca} 2+$ and $\mathrm{Cl}-$ loss. Increased level of an antioxidant enzymes such as SOD, catalase (CAT), GPx, GR and GST was observed. Nephroprotective effect was proved [24].

\section{Action against atopic dermatitis}

P. santalinus and Buddleia officinalis exhibited synergism in treating skin inflammation, especially atopic dermatitis by inhibition of thymic stromal lymphopoietin and interleukin (IL)-4/polyinosinicpolycytidylic acid. Inhibition led to reduction in inflammation and proinflammatory cytokines and inflammatory markers [25].

P. santalinus ethanol extract decreased the degranulation of IgEsensitized rat basophilic leukemia-2H3 mast cells and release of allergic mediators such as histamine and $\beta$-hexosaminidase in a dose-dependent manner. Extract treatment further inhibited the production of the pro-inflammatory cytokines (TNF- $\alpha$ and IL-4) and prostaglandin E2 production contributing to action against atopic 
Table 1: Phytochemistry of $P$. santalinus [8-10]

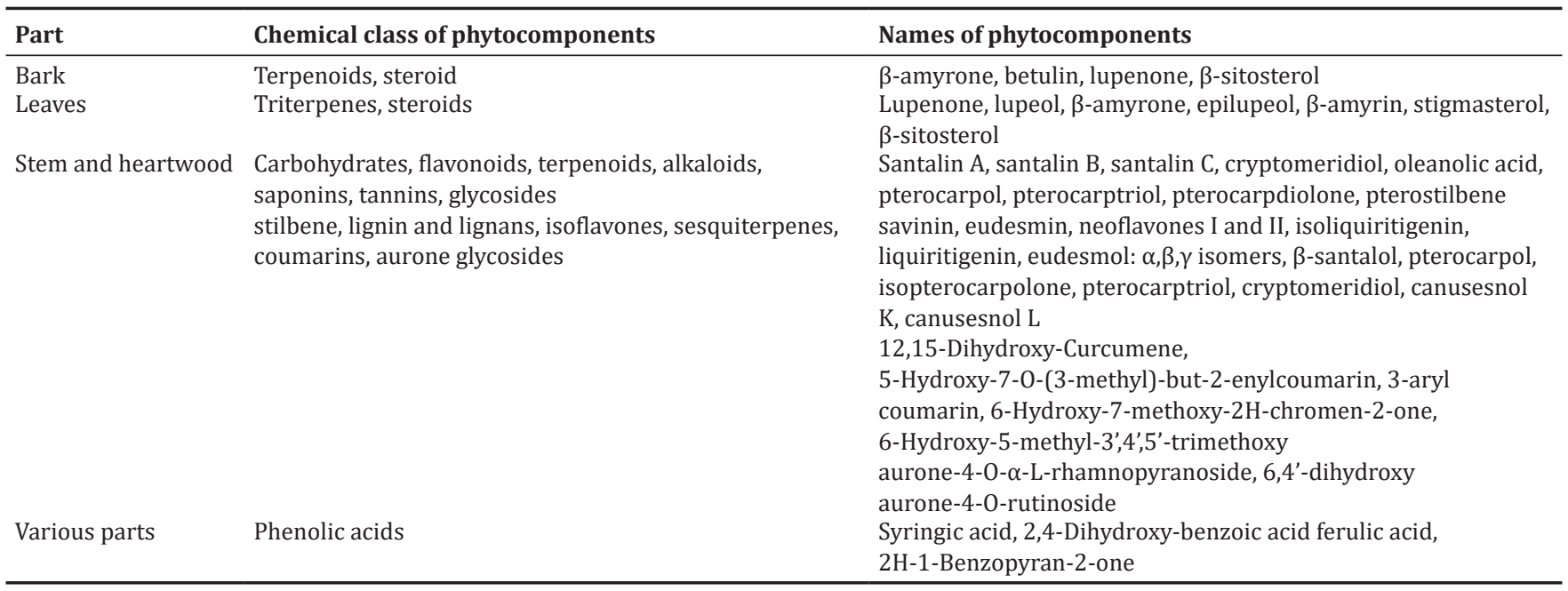

dermatitis. 2,4-dinitrochlorobenzene-induced atopic dermatitis model in NC-Nga mice proved P. santalinus extract to reduce inflammatory cell infiltration, skin hypertrophy and epidermal thickening. Flavonoids, namely, taxifolin, quercetin and protocatechuic acid have antiinflammatory activity may be responsible for the activity [26].

\section{Protection against $\mathrm{UV}-\mathrm{B}$ radiation}

Ethanol extract of $P$. santalinus exhibited protective and anti-photoaging effect against UV-B irradiated human dermal fibroblasts by regulating the levels of matrix metalloproteinases, interleukin-6 (tissue destruction and inflammatory response mediators), checked phosphorylation of extracellular signal-regulated kinase, Jun $\mathrm{N}$-terminal kinase and p38 mitogen-activated protein kinase and activated AP-1 transcription factors which aided tissue regeneration [27].

\section{Anti-tyrosinase activity}

Inhibition of tyrosinase, tyrosinase-related protein 1 (TRP-1), TRP2 and microphthalmia-associated transcription factor (MITF): In vitro studies on B16F0 melanoma cells proved the inhibitory effect of santalin by downregulation of tyrosinase, tyrosinase-related protein 1 (TRP-1) and tyrosinase-related protein 2 (TRP-2) and MITF (precursors for melanogenesis) and thereby proposed the role in treating hyperpigmentation [28].

\section{Wound healing activity}

Wound healing potential of $P$. santalinus gel formulation was studied by Biswas et al. on male Charles Foster rats. It was observed that there is significant wound contraction, less period of epithelization, enhanced hydroxyproline content and collagen content in the gel treated group. $P$. santalinus was found to stimulate the generation of proteins and factors which regenerated the extracellular matrix and potentiated wound healing [29].

\section{Anti-ulcer activity}

Protective effect of the ethanol extract of heartwood of P. santalinus against gastric ulcers induced by ibuprofen was proved in rats as it normalized the sodium and potassium ion concentration and thus regulated gastric acid stimulation [30]. Ethanol extract of heartwood of $P$. santalinus inhibited the growth of Helicobacter pylori in rat gastric epithelial cells and reduced urease activity which promoted its growth [31].

\section{Treatment of menorrhagia (Dysfunctional uterine bleeding)}

In the study by Mishra et al., P. santalinus along with Berberis aristata, Rasanjana (extract of B. aristata in milk), Swertia chirata, Cyperus rotundus, Aegle marmelos, Calotropis procera and Adhatoda vasica in the form of decoction (Dravya kadikashay) and intrauterine instillation of Dravyadi Tail were evaluated in women suffering from menorrhagia. Results suggested decreased duration and magnitude of menstrual blood loss, normalized consecutive menstrual cycles. Attenuation of raised biomarker serum vascular endothelial growth factor-A (VEGF-A) improved the symptoms of menorrhagia by decreased fibrinolytic and vasodilatory effects on the endometrium [32].

\section{Treatment of acne vulgaris}

Herbal formulation containing Emblica officinalis, Citrus aurantium, Psidium guajava, Aloe vera, Curcuma longa, A. indica, P. santalinus and Ocimum sanctum can be used for acne treatment due to its bacteriostatic effect on acne causing S. aureus and E. coli. P. santalinus possessed soothing and cooling effect on the skin and relieved from symptoms such as pain and redness [33].

\section{Treatment of neonatal jaundice}

Amruta Abheervadi drops are used for treating neonatal jaundice in Ayurveda. Amruta Abheervadi drops contain Tinospora cordifolia, Asparagus racemosus (Abheeru), Tricosanthesdiocia, A. indica, $P$. santalinus and Hemidesmus indicus [34].

\section{Protective action against gamma radiation}

Polyphenols extracted from $P$. santalinus hydroalcoholic extract, namely, vanillic acid, chlorogenic acid, protocatechuic acid, rosmarinic acid, eudesmin and astragalin protected against gamma radiation-induced inflammation, cytotoxicity and lipid peroxidation in in vitro and in vivo studies [21].

\section{Anticancer activity}

Methanol extract of $P$. santalinus tested against stem-induced apoptosis in human cervical adenocarcinoma cell line (HeLa cell line) worked through apoptosis mechanism. Proteolytic cleavage of poly-ADP ribose polymerase-activated caspase-3,8,9, leading to apoptosis and loss of cell viability, DNA fragmentation, chromatin condensation, DNA fragmentation and sub-G1 phase accumulation [35].

\section{Anti-adipogenesis and associated inflammation}

In vitro anti-adipogenic and anti-inflammatory potential of chloroform extract of $P$. santalinus heartwood at $200 \mu \mathrm{g} / \mathrm{ml}$ was evident on 3T3L1 cell line due to downregulation of PPAR- $\gamma$ and SREBP-1cmediated decreased lipid accumulation, triglyceride accumulation and inflammatory markers, TNF- $\alpha$ and IL-6. Enhanced adiponectin and mRNA expression of fat burning protein UCP-1 improved effective against adipogenesis, insulin resistance, inflammation and obesity [36].

Pharmacological activities of various parts of $P$. santalinus are given in Table 2. 


\section{DERMATOLOGICAL APPLICATIONS OF PHYTOCONSTITUENTS OF P. SANTALINUS}

Pterostilbene and cream formulation with $0.4 \%$ pterostilbene protected against UV-induced sunburn (erythema), photoaging, tanning and mutagenicity. Sunscreen protection factor indicated the protection against UV-B rays. Pterostilbene scavenges free radicals produced due to oxidative stress caused by UV-B radiation exposure. Pterostilbene proves to have vital role in sunscreen formulations [37]. Promising UV-B rays protective effect of liposomal formulation of pterostilbene was seen in a study by Sirerol et al. on female SKH-1 hairless mice. Pterostilbene treatment protected from photoaging, inflammation and skin wrinkling after acute UV-B radiation $(360 \mathrm{~mJ} / \mathrm{cm} 2)$ and prevented skin carcinogenesis in mice due to chronic UV-B irradiation $\left(180 \mathrm{~mJ} / \mathrm{cm}^{2}\right.$, three doses in a week for 30 weeks) by upregulation of antioxidant enzymes, glutathione, CAT, superoxide and glutathione peroxidase, as a result of transcription factor nuclear factor erythroid 2-related factor 2 (Nrf2) activation, the antioxidant response element (ARE) causing expression of antioxidant enzymes [38].
A cream formulation with $0.4 \% \mathrm{w} / \mathrm{w}$ pterostilbene possessed in vitro anti-melanogenic activity and in vivo skin brightening and anti-aging effect. In vitro study proved inhibition of tyrosinase, collagenase and elastase enzymes. The cream was found to hydrate, repair, rejuvenate the skin and reduce fine lines and wrinkles in healthy male and female volunteers. The activation of cytoplasmic and surface membrane estrogen receptors by pterostilbene maintains skin elasticity and collagen content, reduced wrinkles and promoted hydration [39].

Savinin was found to downregulate UV radiation-induced expression of metalloproteinases by blocking the DNA binding site of photo-induced of AP-1 transcription factor in an in silico study. Downregulation of metalloproteinases may restore the skin integrity, elasticity and tensile strength by decreased degradation of collagen and extracellular matrix proteins and protect from photoaging of the skin [40]. Cedrol isolated from Pterocarpus genus proved to be a promising anti-wrinkle agent by enhancing dermal fibroblast cell proliferation, leading to

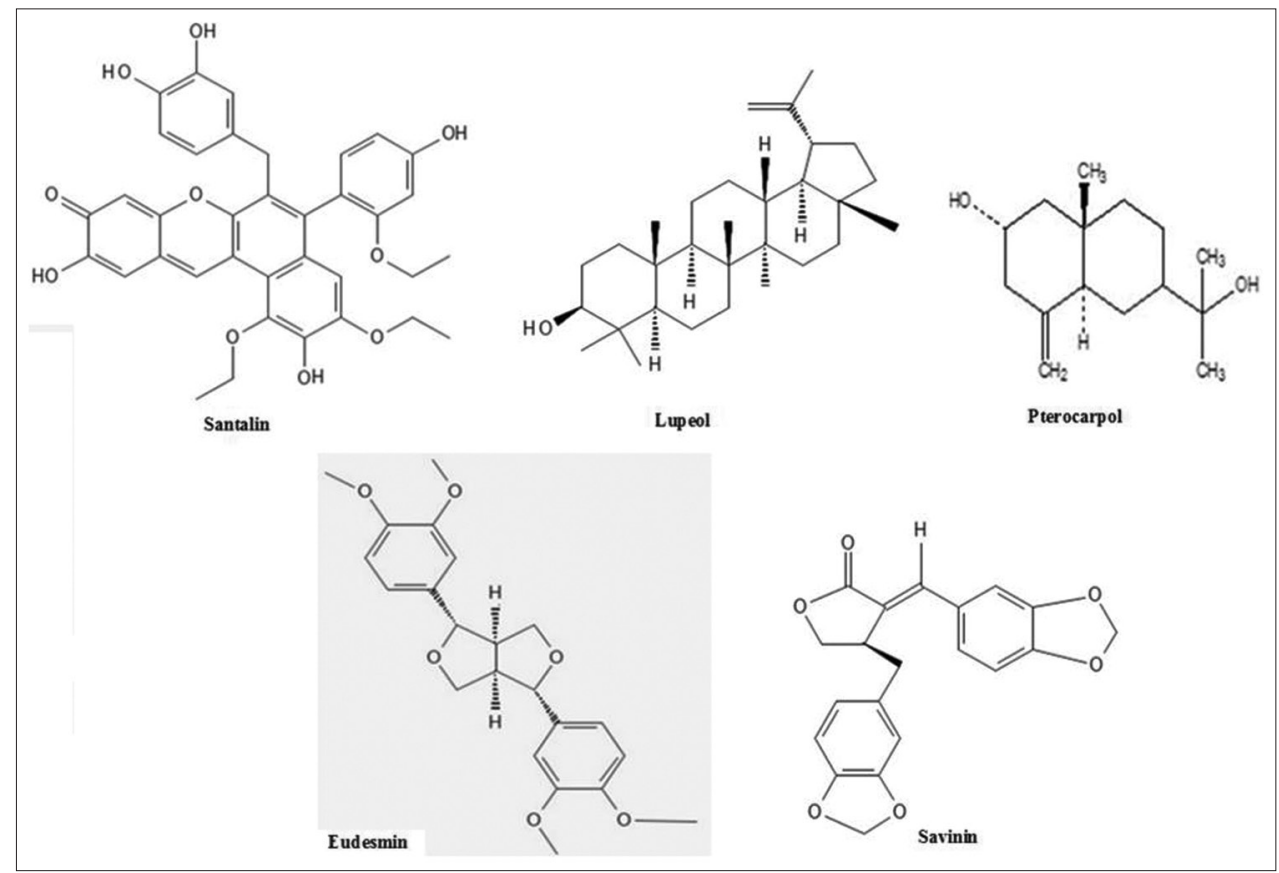

Fig. 1: Phyto-constituents present in Plant

\begin{tabular}{|c|c|c|c|}
\hline Pharmacological actions & Part used & Extract & Mechanism of action \\
\hline Anticholinesterase & Bark & Methanol & $\begin{array}{l}\text { Inhibition of brain acetylcholinesterase and enhancement in } \\
\text { memory in mice }\end{array}$ \\
\hline Antifungal & Leaves & Ethyl acetate & Disruption of the fungal cell wall by flavonoids \\
\hline Hypoglycemic effect & Bark & Aqueous, ethanol, hexane & $\begin{array}{l}\text { Activation of the remnant beta cells and improvement in insulin } \\
\text { response at cellular level }\end{array}$ \\
\hline Antipyretic & Heartwood & Aqueous & $\begin{array}{l}\text { Prevention of activation of cyclooxygenase and prostaglandin } \\
\text { formation }\end{array}$ \\
\hline Antibacterial & Bark and leaves & Methanol & $\begin{array}{l}\text { Inactivation of microbial enzymes, transport proteins and } \\
\text { adhesins, loss of cell membrane integrity }\end{array}$ \\
\hline Hepatoprotective effect & Heartwood & Methanol & Enhancement of antioxidant enzymes in the liver in rats \\
\hline Nephroprotective & Heartwood & Methanol & $\begin{array}{l}\text { Enhancement of antioxidant enzymes SOD, CAT, GPx, GR and GST in } \\
\text { the kidney in rats. }\end{array}$ \\
\hline Antityrosinase & Heartwood & Acetone extract & $\begin{array}{l}\text { Downregulation of tyrosinase, TRP-1TRP-2 and MITF (precursors } \\
\text { for melanogenesis) }\end{array}$ \\
\hline Wound healing & Stem powder & - & $\begin{array}{l}\text { Stimulation of generation of proteins and factors which } \\
\text { regenerated the extracellular matrix. }\end{array}$ \\
\hline Anti-ulcer & Heartwood & Ethanol & Anti-Helicobacter pylori \\
\hline
\end{tabular}

SOD: Superoxide dismutase, CAT: Catalase, GPx: Glutathione peroxidase, GR: Glutathione reductase, GST: Glutathione S-transferase 
increased collagen and elastin synthesis through intracellular signaling pathways [41].

In addition, cedrol can be used as a fragrance material in cosmetics and non-cosmetic preparations [42]. Topical application of cedrol (200 mg/kg) ameliorated cyclophosphamide-induced hair damage and alopecia. Restoration of hair growth and normal hair follicles with abundant melanin content in cedrol-treated mice was attributed to suppression of p53 protein transcription-induced hair follicle apoptosis, activation of MAPK and ERK intracellular signaling pathways prevent apoptosis and protect dermal fibroblasts [43].

Betulin, a terpenoid, found in $P$ santalinus modulated 7,12-dimethylbenzanthracene and 12-0-tetradecanoylphorbol 13-acetate (TPA)-induced skin cancer in in vivo and ex vivo studies in mice as evident from spectral signatures of surface-enhanced Raman spectroscopy [44]. Betulin oleogel formulation showed promising antiinflammatory and anti-tumor potential against actinic keratoses [45]. Betulin also showed promising candidate as a wound healing agent by promoting reepithelization of wounds in a Phase-III clinical trial [46]. Isoliquiritigenin and beta-sitosterol found in the heartwood and bark proved to be useful in atopic dermatitis by suppressing inflammatory cytokines, chemokine and IgE antibody production [47]

Ferulic acid acts as an antioxidant against UV-A and UV-B radiation in keratinocytes and fibroblasts by scavenging reactive oxygen species preventing carcinogenesis and elastosis. Decrease in metalloproteinases supports its role as anti-photoaging agent. It has shown to accelerate wound healing by enhancing collagen [48]. $\alpha$-Bisabolol, a sesquiterpene alcohol, isolated by Jiang et al., from $P$. santalinus has a role in cosmetic formulations as a depigmentation agent by inhibiting melanocytestimulating hormone-induced cAMP and tyrosinase activation and as a permeation enhancer $[49,50]$. $\beta$-eudesmol was found to inhibit nuclear factor-kappa B (NF- $\mathrm{KB})$ and metalloproteinases activation in human dermal fibroblasts. DPPH radical scavenging activity assay, glutathione (GSH) estimation proved its anti-inflammatory and antiaging potential [51]

Syringic acid found in $P$. santalinus inhibited UV-B-induced skin cancer in vitro and in vivo by inhibition of inflammatory responses (cyclooxygenase-2, matrix metalloproteinase-1 and prostaglandin E2 expression), inhibition of phosphorylation of mitogen-activated protein kinases, Akt 11 signaling pathways, epidermal growth factor receptor and protein-tyrosine 13 phosphatase- $\kappa$ activity [52].

Lupeol and its ester derivatives have skin damage healing property and in vivo studies prove its use as a wound and burn healing agent $[53,54]$.

\section{DIVERSE APPLICATIONS OF P. SANTALINUS}

\section{Santalin as a histological stain}

Histological stain of santalin isolated from the heartwood of $P$. santalinus to stain histological tissues was prepared by Sengupta et al. Santalin was found to be remarkable nuclear material stain. Santalin stained striations on the voluntary tissues, Nissl granules and cranial nerve fibers in the pons, thin elastic fibrils and thick elastic fibers in the skin tissue and chromatid bars and nucleus in Entamoeba histolytica cysts [55].

\section{Antidote for snake and scorpion bite}

Stem bark of $P$. santalinus along with garlic and pepper is ground together and infusion is prepared and given orally as an antidote for snakebite [56]. In India, the heartwood is used as an antidote for scorpion bite [57].

\section{TOXICITY STUDIES}

Azamthulla et al. studied the acute toxicity profile of ethanol and chloroform extract in five groups of adult female Wistar rats, at doses $50,500,1000$ and $2000 \mathrm{mg} / \mathrm{kg}$, respectively, no mortality and toxic effects were seen up to the dose of $2 \mathrm{~g} / \mathrm{kg}$ in $24 \mathrm{~h}$. Adult male Wistar rats were orally administered ethanol and chloroform extract of four groups at doses 100,400 and $750 \mathrm{mg} / \mathrm{kg}$, respectively, twice daily and for 28 for subacute toxicity study. No behavioral, locomotor and biochemical toxic effects were observed in the toxicity studies [58].

However, allergic contact dermatitis was observed in a woman in India, after applying $P$. santalinus bark powder paste for 2 months. Symptoms included itchy erythema and edema over the post-chickenpox scars were found to diminish after topical corticosteroid treatment [59].

\section{CONCLUSION}

This review entails brief description on the phytoconstituents and pharmacological activities of $P$. santalinus. Phytoconstituents, namely, terpenoids, flavonoids and pterostilbene are responsible for the neuroprotective, antimicrobial, hypoglycemic, antipyretic, antiinflammatory and hepatoprotective activities. Santalin plays a peculiar role in the holistic utilization of $P$. santalinus in the fields of dyeing staining, therapeutic and cosmetics. Indeed, $P$. santalinus is a treasure of health.

\section{ACKNOWLEDGMENTS}

Authors are thankful to Dr. Pravin. D. Chaudhari, Professor and Principal, Modern College of Pharmacy, Nigdi, Pune, for their constant guidance, motivation and being supportive during project.

\section{AUTHORS' CONTRIBUTIONS}

Dr. Mohini Chetan Kuchekar conceptualized the idea, writing and reviewed the manuscript. Vijay Navghare wrote, reviewed and finalized the manuscript. Amrita Milind Kulkarni, Aishwarya Avinash Zambare and Bharti Jagdish Choudhary contributed in information collection and writing the paper. All authors read and approved the final manuscript.

\section{CONFLICTS OF INTEREST}

All authors declare that we have no conflicts of interest.

\section{AUTHORS' FUNDING}

No funding for article writing needed.

\section{ETHICS APPROVAL AND CONSENT TO PARTICIPATE}

Not applicable.

\section{REFERENCES}

1. Zhang M, Zhao G, Guo J, Liu B, Jiang X, Yin Y. A GC-MS protocol for separating endangered and non-endangered Pterocarpus wood species. Molecules 2019;24:799.

2. Gupta A, Tandon N, Sharma M. Quality Standards of Indian Medicinal Plants. Vol. 6. New Delhi: ICMR; 2008.

3. Giriraj A, Shilpa G, Reddy CS, Sudhakar S, Beierkuhnlein C, Murthy MS. Mapping the geographical distribution of Pterocarpus santalinus L.f (Fabaceae)-an endemic and threatened plant species using ecological niche modeling. In: Proceedings of the National Seminar on Conservation of Eastern Ghats, EPTRI; 2008. p. 446-57.

4. Jaime A, Teixeira S, Mafatlal MK, Deepak S, Nataraj M. Red sandalwood (Pterocarpus santalinus L. F.): Biology, importance, propagation and micropropagation. J For Res 2018;30:745-54.

5. Mahato G, Hansda B, Banerjee N. Ethnobotanicals used for the treatment of skin diseases with special emphasis on carbuncle disease from Purulia district of West Bengal in India. Pharmacogn J 2019;11:745-53.

6. Raghunathan M. An ethnomedicinal survey of medicinal plants utilized by folk people of the Thrissurforest circle, Kerala. Eur J Pharm Med Res 2017;4:401-9.

7. Pullaiah T, Divakara BN. Wood uses, ethnobotany and pharmacognosy. In: Pullaiah T, Balasubramanya S, Anuradha M, editors. Red Sanders: Silviculture and Conservation. Singapore: Springer; 2019. p. 17-26.

8. Pullaiah T, Reddy VD, Umalatha, Rashmi BS. Chemistry of red sanders. In: Pullaiah T, Balasubramanya S, Anuradha M, editors. Red Sanders: 
Silviculture and Conservation. Singapore: Springer; 2019. p. 36-44.

9. Li L, Tao RH, Wu JM, Guo YP, Huang C, Liang HG, et al. Three new sesquiterpenes from Pterocarpus santalinus. J Asian Nat Prod Res 2018;20:306-12

10. Kesari AN, Gupta RK, Watal G. Two aurone glycosides from heartwood of Pterocarpus santalinus. Phytochemistry 2004;65:3125-9.

11. Biswas K, Armin UH, Prodhan SM, Prithul JA, Sarker S, Afrin F. In vitro and in vivo assessment of cholinesterase inhibitory activity of the bark extracts of Pterocarpus santalinus L. for the treatment of Alzheimer's disease. Int J Pharm 2018;12:550-3.

12. Arokiyaraj S, Perinbam K. Antifungal activity of Pterocarpus santalinus-an in vitro study. Biomed Pharmacol J 2010;3:263-5.

13. Rao BK, Giri R, Kesavulu MM, Apparao CH. Effect of oral administration of bark extracts of Pterocarpus santalinus L. on blood glucose level in experimental animals. J Ethnopharmacol 2001;74:69-74.

14. Kondeti VK, Badri KR, Maddirala DR, Thur SK, Fatima SS, Kasetti $\mathrm{RB}$, et al. Effect of Pterocarpus santalinus bark, on blood glucose, serum lipids, plasma insulin and hepatic carbohydrate metabolic enzymes in streptozotocin-induced diabetic rats. Food Chem Toxicol 2010;48:1281-7.

15. Vasudevan CN, Kariyil BJ. Antipyretic activity of aqueous extract of heart wood of Pterocarpus santalinus L. in yeast induced pyrexia. J Pharmacogn Phytochem 2019;8:244-6.

16. Manjunatha BK. Antibacterial activity of Pterocarpus santalinus. IJPS 2006;68:115-6

17. Keshavamurthy M, Srinath BS, Rai VR. Phytochemicals-mediated green synthesis of gold nanoparticles using Pterocarpus santalinus L. (Red Sanders) bark extract and their antimicrobial properties. Part Sci Technol 2018;36:785-90

18. Dhande P, Gupta A, Jain S, Dawane J. Anti-inflammatory and analgesic activities of topical formulations of Pterocarpus santalinus powder in rat model of chronic inflammation. J Clin Diagn 2017;11:1-4.

19. Cho JY, Park J, Kim PS, Yoo ES, Baik KU, Park MH. Savinin, a lignan from Pterocarpus santalinus inhibits tumor necrosis factor- $\alpha$ production and T cell proliferation. Biol Pharm Bull 2001;24:167-71.

20. Bulle S, Reddy VD, Padmavathi P, Maturu P, Varadacharyulu NC. Modulatory role of Pterocarpus santalinus against alcohol-induced liver oxidative/nitrosative damage in rats. Biomed Pharmacother 2016;83:1057-63.

21. Ghali EH, Maurya DK, Meriga B. Radioprotective properties of Pterocarpus santalinus chloroform extract in murine splenic lymphocytes and possible mechanism. Cancer Biother Radiopharm 2018;33:427-37.

22. Donga S, Pande J, Moteriya P, Chanda S. In vitro cytotoxicity study of leaf, stem and bark of Pterocarpus santalinus Linn. F. Int J Pharmacogn 2017;6:297-305.

23. Akhouri V, Kumar A, Kumari M. Antitumour property of Pterocarpus santalinus seeds against DMBA-induced breast cancer in rats. Breast Cancer (Auckl) 2020;14:1-9.

24. Bulle S, Reddy VD, Hebbani AV, Padmavathi P, Challa C, Puvvada PK, et al. Nephroprotective action of $P$. santalinus against alcoholinduced biochemical alterations and oxidative damage in rats. Biomed Pharmacother 2016;84:740-6.

25. Kim M, Lee KE, Nam JJ, Kim Y. Inhibitory effect of Pterocarpus santalinus and Buddleia officinalis on mediator of skin inflammation, especially atopic dermatitis. J Am Acad Dermatol 2016;80:911-9

26. Ham B, Kim M, Son YJ, Chang S, Jung SH, Nho CW, et al. Inhibitory effects of Pterocarpus santalinus extract against IgE/antigen-sensitized mast cells and atopic dermatitis-like skin lesions. Planta Med 2019;85:599-607.

27. Gao W, Lin P, Hwang E, Wang Y, Yan Z, Ngo HT, et al. Pterocarpus santalinus $\mathrm{L}$. regulated ultraviolet $\mathrm{B}$ irradiation-induced procollagen reduction and matrix metalloproteinases expression through activation of TGF- $\beta /$ smad and inhibition of the MAPK/AP-1 pathway in normal human dermal fibroblasts. Photochem Photobiol 2018;94:139-49.

28. Hridya H, Amrita A, Mohan S, Gopalakrishnan M, Dakshinamurthy TK, Doss GP, et al. Functionality study of santalin as tyrosinase inhibitor: A potential depigmentation agent. Int J Biol Macromol 2016;86:383-9.

29. Biswas TK, Maity LN, Mukherjee B. Wound healing potential of Pterocarpus santalinus Linn: A pharmacological evaluation. Int J Low Extrem Wounds 2004;3:143-50.

30. Narayan S, Devi RS, Srinivasan P, Devi CS. Pterocarpus santalinus: A traditional herbal drug as a protectant against ibuprofen induced gastric ulcers. Phytother Res 2005;19:958-62.

31. Narayan S, Veeraraghavan M, Devi CS. Pterocarpus santalinus: An in vitro study on its anti-Helicobacter pylori effect. Phytother Res
2007;21:190-3.

32. Sinha M, Byadgi PS, Mishra S. Effect of polyherbal drug on menorrhagia and its evaluation by assessing biomarker serum VEGF-A. Int J Environ Ecol Fam Urban Stud 2018;8:1-16.

33. Sreeja M, Gourishanker NL, Aswathi M, Dhanuja EV. Formulation and evaluation of herbal cream for acne. Sciences 2018;7:2292-5.

34. Rathore S, Kumar VC, Sharaschandra R. Preparation of Amruta abheervadi drops: An ayurvedic formulation for neonatal jaundice. J Pharma Innov 2018;7:323-6.

35. Kwon HJ, Hong YK, Kim KH, Han $\mathrm{CH}$, Cho SH, Choi JS, et al. Methanolic extract of Pterocarpus santalinus induces apoptosis in HeLa cells. J Ethnopharmacol 2006;105:229-34.

36. Sankaran KR, Ganjayi MS, Oruganti L, Chippada AR, Meriga B. A bioactive fraction of Pterocarpus santalinus inhibits adipogenesis and inflammation in 3T3-L1 cells via modulation of PPAR- $\gamma /$ SREBP$1 \mathrm{c}$ and TNF- $\alpha /$ IL-6. 3 Biotech 2021;11:233

37. Majeed M, Majeed S, Jain R, Mundkur L, Rajalakshmi HR, Lad P, et al. A randomized study to determine the sun protection factor of natural pterostilbene from Pterocarpus marsupium. Cosmetics 2020;7:16.

38. Sirerol JA, Feddi F, Mena S, Rodriguez ML, Sirera P, Aupí M, et al. Topical treatment with pterostilbene, a natural phytoalexin, effectively protects hairless mice against UVB radiation-induced skin damage and carcinogenesis. Free Radic Biol Med 2015;85:1-11.

39. Majeed M, Majeed S, Jain R, Mundkur L, Rajalakshmi HR, Lad PS, et al. An open-label single-arm, monocentric study assessing the efficacy and safety of natural pterostilbene (Pterocarpus marsupium) for skin brightening and antiaging effects. Clin Cosmet Investig Dermatol 2020;13:105-15.

40. Ophelia EF, Sujatha PL, Kumarasamy P. Screening of bioactive compounds from natural remedies for photoaging, to target Ap-1; an in silico approach. In: $20162^{\text {nd }}$ International Conference on Advances in Electrical, Electronics, Information, Communication and BioInformatics (AEEICB). 2016. p. 488-90.

41. Jin MH, Park SG, Hwang YL, Lee MH, Jeong NJ, Roh SS, et al. Cedrol enhances extracellular matrix production in dermal fibroblasts in a MAPK-dependent manner. Ann Dermatol 2012;24:16-21.

42. Bhatia SP, McGinty D, Letizia CS, Api AM. Fragrance material review on cedrol. Food Chem Toxicol 2008;46:100-2.

43. Chen SS, Zhang Y, Lu QL, Lin Z, Zhao Y. Preventive effects of cedrol against alopecia in cyclophosphamide-treated mice. Environ Toxicol Pharmacol 2016;46:270-6.

44. Falamas A, Dehelean CA, Pinzaru SC. Monitoring of betulin nanoemulsion treatment and molecular changes in mouse skin cancer using surface enhanced Raman spectroscopy. Vib Spectrosc 2018;95:44-50.

45. Huyke C, Reuter J, Rodig M, Kersten A, Laszczyk M, Scheffler A, et al. Treatment of actinic keratoses with a novel betulin-based oleogel. A prospective, randomized, comparative pilot study. J Dtsch Dermatol Ges 2009;7:128-33.

46. Barret JP, Podmelle F, Lipový B, Rennekampff HO, Schumann H, Schwieger-Briel A, et al. Accelerated re-epithelialization of partialthickness skin wounds by a topical betulin gel: Results of a randomized phase III clinical trials program. Burns 2017;43:1284-94.

47. Yu H, Li H, Li Y, Li M, Chen G. Effect of isoliquiritigenin for the treatment of atopic dermatitis-like skin lesions in mice. Arch Dermatol Res 2017;309:805-13.

48. Zduńska K, Dana A, Kolodziejczak A, Rotsztejn H. Antioxidant properties of ferulic acid and its possible application. Skin Pharmacol Physiol 2018;31:332-6

49. Jiang S, Wei Y, Liu Z, Ni C, Gu H, Peng W. Molecules and functions of rosewood: Pterocarpus santalinus. J King Saud Univ Sci 2020;32:1712-7

50. Kamatou GP, Viljoen AM. A review of the application and pharmacological properties of $\alpha$-bisabolol and $\alpha$-bisabolol-rich oils. J Am Oil Chem Soc 2010;87:1-7.

51. Kim KY. Anti-inflammatory and ECM gene expression modulations of $\beta$-eudesmol via NF- $\kappa$ Bsignaling pathway in normal

human dermal fibroblasts. Biomed Dermatol 2018;2:1-2.

52. Ha SJ, Lee J, Park J, Kim YH, Lee NH, Kim YE, et al. Syringic acid prevents skin carcinogenesis via regulation of NoX and EGFR signaling. Biochem Pharmacol 2018;154:435-45.

53. Beserra FP, Gushiken LF, Vieira AJ, Bérgamo DA, Bérgamo PL, de Souza MO, et al. From inflammation to cutaneous repair: Topical application of lupeol improves skin wound healing in rats by modulating the cytokine levels, NF- $\mathrm{BB}, \mathrm{Ki}-67$, growth factor expression, and distribution of collagen fibers. Int J Mol Sci 2020;21:4952.

54. Malinowska M, Miroslaw B, Sikora E, Ogonowski J, Wojtkiewicz AM, 
Szaleniec M, et al. New lupeol esters as active substances in the treatment of skin damage. PLoS One 2019;14:1-15.

55. Sen Gupta PC, Mukherjee AK. Newer applications of the histological stain prepared from Pterocarpus santalinus. Stain Technol 1981;56:79-82.

56. Padma Y, Sarojinidevi N, Ratnam KV, Reddy GT, Raju RV. Herbal/folk remedies used for snake bites by tribals/rural people of Rayalaseema region, Andhra Pradesh. J Med Plants Res 2016;4:52-6.
57. Bahekar S, Kale R, Nagpure S. A review on medicinal plants used in scorpion bite treatment in India. Mintage J Pharm Med Sci 2012;1:16.

58. Azamthulla M, Balasubramanian R, Kavimani S. Acute and subacute toxicity of Pterocarpus santalinus heartwood extracts in rats. Int J Front Sci Technol 2013;1:99-113.

59. Sandra A, Shenoi SD, Srinivas CR. Allergic contact dermatitis from red sandalwood (Pterocarpus santalinus). Contact Dermatitis 1996;34:69. 